DOI: https://doi.org/10.32838/2523-4803/69-6-29

УДК 338.46

Супруненко С.А.

кандидат економічних наук,

доцент кафедри менеджменту,

Університет державної фіскальної служби України

\title{
Suprunenko Svitlana
}

University of State Fiscal Service of Ukraine

\section{СПЕЦИФІКА ФІНАНСОВОГО МЕНЕДЖМЕНТУ У СФЕРІ ДЕРЖАВНИХ ПОСЛУГ}

\begin{abstract}
Статтю присвячено висвітленню специфіки та особливостей фінансового менеджменту у сфері державних послуг. Автором визначено сутність фінансового менеджменту та встановлено основні відмінності фінансового менеджменту у сферах приватних та державних послуг. Проведено короткий аналіз досвіду провідних країн світу у напрямі розвитку фінансового менеджменту в державному секторі, серед яких такі країни, як Велика Британія, Канада, Нідерланди, США. Встановлено прочеси і процедури, які забезпечують результативність використання ресурсів фінансового менеджменту у сфері державних послуг. Окрема увага приділена автором питанням удосконалення фінансового менеджменту, керівниитва, управління ефективністю в організаиії иьього сектору. У дослідженні встановлені основні проблемні аспекти розвитку системи фінансового менеджменту та безпосередньо управління його ефективності в державному секторі в Україні, а також запропоновані шляхи подолання визначених недоліків.
\end{abstract}

Ключові слова: фінансовий менеджмент, державний сектор, приватний сектор, сфера державних послуг, державні послуги, інструменти фінансового менеджменту, бюджет.

Постановка проблеми. У сучасному глобалізованому суспільстві поняття «фінансовий менеджмент» практично не асоціюється зі сферою державних послуг, що пов'язано зі складнощами уявлення застосування органами державної влади або місцевого самоврядування деяких механізмів, які не регламентовані відповідним нормативно-правовим актом, а особливо у фінансовій сфері, де кожне рішення про витрачання коштів пильно розглядається численними контролюючими органами. Державні послуги пов'язані з високим рівнем очікувань з боку населення, у зв'язку з чим закономірно посилюється роль моніторингу та управління якістю цих послуг. Вимоги до рівня відповідальності та прозорості у витрачанні державних коштів останніми роками суттєво зросли, що чинить певний вплив на державні організації і стимулює їх робити більше 3 меншими засобами, бути більш ефективними й оптимізувати витрати. У багатьох країнах сучасне фінансове становище змушує жорстко скорочувати витрати. При цьому посилюється увага до бюджетування, планування і достовірності фінансової інформації.

Аналіз останніх досліджень і публікацій. У процесі дослідження автором були вивчені та проаналізовані праці таких зарубіжних та вітчизняних науковців: Х. Брюйна [1], Д. Курпассона [2], М. Перрі [3], Н.А. Коротіної [4], Ж.П. Лисенко [5], В.В. Міхєєва [6], B.I. Пятанової [7] та деяких інших. У процесі опрацювання наукових доробків низки вчених у сфері фінансового менеджменту та державного управління ми дійшли висновку, що для досягнення головної мети ефективного і відповідального управління суспільними фінансами - надання послуг державної сфери високої якості за підвищення ефективності та результативності бюджетних витрат - необхідно послідовно реформувати всі фази бюджетного циклу шляхом упровадження сучасних процедур і процесів фінансового менеджменту в державний сектор.

Мета статті. Метою дослідження є визначення особливостей фінансового менеджменту у сфері державних послуг.

Виклад основного матеріалу дослідження. Інструменти i процедури фінансового менеджменту в секторі державного і муніципального управління стали активно використовуватися урядами економічно розвинених країн починаючи з другої половини 1980-х рр. До цього часу переважною стала думка, що державні організації, як і приватні компанії, повинні використовувати фінансові кошти з максимальною віддачею. За більш ніж двадцятирічний термін існування практики фінансового менеджменту в державних і муніципальних установах економічно розвинених країн розуміння його сутності і ключових принципів помітно змінилося. Якщо на початковому етапі фінансовий менеджмент розглядався насамперед як інструмент контролю за бюджетними витратами, то нині він розуміється як система керівництва фінансовими ресурсами в межах певної території, яка забезпечує оптимальні способи використання обмежених обсягів бюджетних ресурсів для ефективного 
i результативного досягнення цілей [8, с. 67]. Таким чином, фінансовий менеджмент - це система управління і контролю фінансових сторін діяльності державного органу після досягнення його цілей. Система передбачає надання більшої свободи прийняття рішень тому, хто керує бюджетними витратами і результатами. Фінансовий менеджмент у сфері державних послуг включає в себе такі процеси і процедури, які забезпечують результативність використання ресурсів:

- визначення найбільш ефективних способів використання обмежених ресурсів для досягнення цілей соціально-економічної політики;

- забезпечення ефективного виконання прийнятих рішень;

- делегування відповідальності;

- підзвітність і відповідальність за діяльність і ії результати.

Відзначимо принципові відмінності фінансового менеджменту у сферах приватних та державних послуг (табл. 1).

У більшості країн, де є практика фінансового менеджменту в державному секторі, процедури і стандарти фінансового менеджменту нормативно врегульовані шляхом прийняття відповідних законів (США, Австралія), а також за рахунок створення спеціальних служб (агентств) із фінансового менеджменту в органах виконавчої влади (Швеція, Великобританія). Таким чином, у низці зарубіжних країн уряди проводять внутрішні оцінки якості фінансового менеджменту, які потім використовуються в практиці управління. Найчастіше механізми оцінки якості фінансового менеджменту вбудовані в систему виконавчої влади і $є$ елементами системи моніторингу та контролю [7, с. 108].

У розвинених країнах фінансовий менеджмент у сфері державних послуг визначається таким чином:

1) у теоретичній літературі - як діяльність державних і муніципальних службовців, що включає в себе прийняття рішень і виконання інших функцій, які дозволяють визначати оптимальні способи використання обмежених ресурсів для ефективного і результативного досягнення політичних цілей;

2) у практичних посібниках (на прикладі Великобританії) - як «система керівництва фінансами державної або муніципальної організації та контролю над ними, що сприяє досягненню цілей організації» [10].

Зауважимо, що вихідний пункт фінансового менеджменту у сфері державних послуг - зіставлення витрат із результатами і визначення їх співвідношень. За підсумками розрахунку різних показників (економічності, ефективності, результативності), постійного відстеження їхньої динаміки і факторів, що на них впливають, приймаються, виконуються, коригуються і контролюються управлінські рішення про збільшення або зменшення бюджетних витрат на реалізацію тих чи інших цілей і завдань кожного конкретного відомства. Таким чином, ефективне здійснення належним чином прийнятих рішень втілюється в зміни структури витрат, а ці зрушення, у свою чергу, забезпечують досягнення запланованих результатів

Виходячи з вищевикладених положень, завданням професіоналів у сфері фінансів, що працюють у секторі державних послуг, $є$ посилення та вдосконалення практики фінансового менеджменту. Зокрема, більше уваги повинно приділятися комплексному прогнозуванню, ефективному бюджетуванню і розподілу фінансових ресурсів. Ці напрями розглядаються як пріоритетні у багатьох країнах, оскільки уряди намагаються зберігати фінансову стійкість у волатильному глобальному економічному середовищі. Важливим елементом цього напряму фінансового менеджменту є бюджетування, націлене на результат. Незалежно від того, уряд проходить період економічних труднощів або зростання, необхідно посилити зв'язок між цілями і результатами проведеної політики та бюджетами.

Таблиця 1

Відмінності фінансового менеджменту у сферах приватних та державних послуг

\begin{tabular}{|c|c|c|}
\hline Характеристика & Приватний сектор & Державний сектор \\
\hline $\begin{array}{l}\text { Рівні застосування } \\
\text { фінансового } \\
\text { менеджменту }\end{array}$ & $\begin{array}{l}\text { Застосовується на рівні підприємства або } \\
\text { групи підприємств }\end{array}$ & $\begin{array}{l}\text { Застосовується на рівні галузі, сфери діяльності головних } \\
\text { розпорядників бюджетних коштів або території (органи } \\
\text { державної влади, органи місцевого самоврядування) }\end{array}$ \\
\hline $\begin{array}{l}\text { Цілі фінансового } \\
\text { менеджменту }\end{array}$ & $\begin{array}{l}\text { Головна мета фінансового менеджменту в } \\
\text { приватному секторі - максимізація прибутку } \\
\text { власників підприємства в поточному і пер- } \\
\text { спективному періоді за рахунок збільшення } \\
\text { ринкової вартості бізнесу. }\end{array}$ & $\begin{array}{l}\text { Головна мета фінансового менеджменту в державній } \\
\text { сфері - найбільш ефективне використання фінансо- } \\
\text { вих ресурсів, які належать всьому суспільству. }\end{array}$ \\
\hline $\begin{array}{l}\text { Завдання фінансо- } \\
\text { вого менеджменту }\end{array}$ & $\begin{array}{l}\text { У приватному секторі головне завдання - мак- } \\
\text { симізація прибутку. }\end{array}$ & $\begin{array}{l}\text { У державному секторі головне завдання - надання } \\
\text { більшої кількості громадських послуг належної якості. }\end{array}$ \\
\hline $\begin{array}{l}\text { Управління } \\
\text { ризиками }\end{array}$ & $\begin{array}{l}\text { У приватному секторі ризики мінімізуються } \\
\text { за прийнятного рівня прибутку. }\end{array}$ & $\begin{array}{l}\text { У державному секторі управління ризиками сконцен- } \\
\text { троване в руках фінансових органів, а безпосередньо } \\
\text { головні розпорядники бюджетних коштів виконують } \\
\text { завдання безумовного виконання своїх функцій і дер- } \\
\text { жавних завдань. }\end{array}$ \\
\hline $\begin{array}{l}\text { Формування обсягів } \\
\text { фінансових ресурсів }\end{array}$ & $\begin{array}{l}\text { У приватному секторі проблема формування } \\
\text { необхідного обсягу фінансових ресурсів вирі- } \\
\text { шується, виходячи з планів розвитку бізнесу. }\end{array}$ & $\begin{array}{l}\text { У бюджетній сфері установи діють в межах доведе- } \\
\text { них їм бюджетних асигнувань та лімітів бюджетних } \\
\text { зобов'язань. }\end{array}$ \\
\hline
\end{tabular}

Джерело: складено автором за [9, с.42-43] 
3 огляду на значення і розмір сектору державних послуг в Україні, який знаходиться під пильним наглядом і контролем, нині підвищеною є увага до фінансової дисципліни, прозорості, ефективності витрат, співвідношення між ціною і якістю в цьому секторі. На практиці це означає, що фінансисти в сфері державних послуг повинні обгрунтувати, що бюджети сформовані відповідно до цілей проведеної політики, що вибір постачальників є оптимальним 3 погляду співвідношення між ціною і якістю, а фінансова звітність $€$ прозорою і достовірною, що кінцевий споживач послуг отримає цінність за гроші.

Панівна сьогодні тенденція до використання як фінансової, так і нефінансової інформації та звітності поширюється все більше і на сектор державних послуг. Так, практика використання інтегрованої звітності впроваджується і в сферу державних послуг. Однак тут може виникнути потенційна проблема, оскільки межі інтегрованої звітності сформовані більше для бізнесспільноти, ніж для державного сектору. Для вирішення цієї проблеми Міжнародна рада 3 інтегрованої звітності розробила передову мережу для державного сектору, за допомогою якої державні організації можуть досліджувати і дискутувати, як інтегрована звітність може бути застосовна в цьому секторі.

Істотну роль в досягненні результативності та якості державних послуг відіграє управління ефективністю фінансового менеджменту. Управління ефективністю має грунтуватися на роботі з прозорою і достовірною інформацією про те, наскільки якісно і своєчасно надаються державні послуги, чи досягається мета «цінність за гроші», а також як і де можна впровадити поліпшення. Система управління ефективністю не повинна створювати надмірне навантаження у вигляді моніторингу та звітності. Вона повинна відповідати завданням, бути легкою для розуміння і використання.

Цікавим у цьому напрямі є досвід розвинених країн. Наприклад, у Великій Британії сектор державних послуг характеризується сильним і деталізованим управлінням ефективністю з центру (національний індикатор ефективності складається з 188 цілей). Канада і Австралія також розробили досить широкий набір формальних індикаторів і вимог до звітності, але не настільки великий, як у Великій Британії. У Нідерландах асоціація муніципалітетів розробила порівняльну систему показників ефективності - публічну інформацію, яку можна використовувати для порівняння та оцінки сильних і слабких сторін схожих організацій [7, с. 109].

Важливим аспектом ефективності в секторі державних послуг є не тільки кількісні, але і якісні показники послуг, що надаються. Це стосується таких сфер, як освіта, охорона здоров'я, організація харчування в школах, громадський транспорт тощо. Останнім часом все частіше сектор державних послуг працює в партнерстві 3 приватними або з громадськими організаціями. Так, поширена практика, коли постачальник поставляє товар або послуги, вироблені іншою компанією. У таких випадках окремі обов'язки і відповідальність сторін повинні бути чітко прописані в контракті і переглядатися на регулярній основі. Наприклад, під час організації харчування в дитячих садах, школах, лікарнях, якщо постачальник поставляє продукцію іншого виробника, повинна бути передбачена відповідальність за якість і прописаний регламент проведення перевірки місця виробництва.

Що стосується розвитку системи фінансового менеджменту та безпосередньо управління його ефективності в державному секторі в Україні, ця система в нині містить низку проблем, серед яких варто виокремити:

- наявність великої кількості бюджетних ризиків;

- відсутність національної системи показників оцінки ефективності фінансового менеджменту;

- можливість суб'єктивної інтерпретації встановлених показників.

У зв'язку з цим основними напрямами вдосконалення системи фінансового менеджменту у сфері державних послуг можуть бути:

- необхідність упровадження інформаційно-аналітичних інструментів, програмного забезпечення, спрямованого на збір і аналіз інформації про поточний стан цієї системи;

- вдосконалення інформаційної системи взаємодії 3 питань якості та контролю на всіх рівнях управління;

- оптимізація показників оцінки ефективності цієї системи;

- підготовка кваліфікованих кадрів державного сектору.

Висновки. Підводячи підсумки, необхідно відзначити, що процес інтеграції механізму фінансового менеджменту сфери державних послуг в реальний бюджетний процес, здійснюваний головними розпорядниками бюджетних коштів, передбачає необхідність формування гіпотез, що вимагають перевірки на практиці, застосування кращих практик фінансового менеджменту на підставі аналізу міжнародного досвіду, розроблення оригінальних ідей, спрямованих на вирішення нетривіальних завдань. При цьому неминучою є наявність помилок, які потребують аналізу. Саме в результаті аналізу визначається раціональний i єдино правильний напрям подальшого розвитку. Всі ці аспекти становлять комплексне завдання, що стоїть перед всіма учасниками бюджетного процесу. Його вирішення дасть змогу 3 упевненістю говорити про практичну значущість процесу фінансового менеджменту для сфери державних послуг. 
Список літератури:

1. Брюйн Х. Управление по результатам в государственном секторе. Москва: Институт комплексных стратегических исследований, 2009. 290 с.

2. Courpasson D., Reed M. Introduction: Bureaucracy in the age of enterprise. Organization. 2004. № 11(1). P. 5-12.

3. Parry M. The Four Dimensions of Public Financial Management. URL: https://ru.scribd.com/document/32869877/ The-Four-Dimensions-of-Public-Financial-Management (дата звернення 10.11.2019)

4. Коротина Н.А. Теоретические основы государственного и муниципального финансового менеджмента. Социум и власть. 2014. № 5(49). С. 86-90.

5. Лисенко Ж.П. Бюджетування як інструмент забезпечення стратегічного та поточного планування. Наукові праиі Національного університету харчових технологій. 2012. № 45. С. 191-195.

6. Михеев В.В. Финансовый менеджмент в муниципальном секторе. Практика муниципального управления. 2010. № 7. C.101-108.

7. Пятанова В.И. Направления совершенствования финансового менеджмента в секторе государственных услуг. Вестник РЭУ им. Г.В. Плеханова. 2017. № 4(94). С.106-110.

8. Афанасьев М.П., Кривогов И.В. Модернизация государственных финансов. Москва: Издательский дом ГУ_ВШЭ, 2007. $312 \mathrm{c}$.

9. Казаковцева М.В. Оценка эффективности финансового менеджмента в государственном секторе. Модели, системьl, сети в экономике, технике, природе и обществе. 2014. № 3(11). С. 40-44.

10. Setting High Professional Standards for Public Services around the World. ACCA Report. URL: http:// graduate.accaglobal.com/content/dam/acca/global/PDF-technical/public-sector/tech-tp-shps4.pdf (дата звернення 12.11.2019).

\section{References:}

1. Bryuyn Kh. (2009) Upravlenie po rezul'tatam v gosudarstvennom sektore [Public sector performance management]. Moscow: Institute for Integrated Strategic Studies. (in Russian)

2. Courpasson D., Reed M. (2004) Introduction: Bureaucracy in the age of enterprise. Organization, vol. 11(1), pp. 5-12.

3. Parry M. The Four Dimensions of Public Financial Management. Available at: https://ru.scribd.com/document/32869877/The-Four-Dimensions-of-Public-Financial-Management (accessed 10 November 2019).

4. Korotina N.A. (2014) Teoreticheskie osnovy gosudarstvennogo i munitsipal'nogo finansovogo menedzhmenta [Theoretical foundations of state and municipal financial management]. Society and power, vol. 5(49), pp. 86-90.

5. Lysenko Zh.P. (2012) Bjudzhetuvannja jak instrument zabezpechennja strateghichnogho ta potochnogho planuvannja [Budgeting as a tool for strategic and ongoing planning]. Science and Technology of the National University of Technology, vol. 45, pp. 191-195.

6. Mikheev V.V. (2010) Finansovyy menedzhment v munitsipal'nom sektore [Municipal financial management]. Municipal management practice, vol. 7, pp. 101-108.

7. Pyatanova V.I. (2017) Napravleniya sovershenstvovaniya finansovogo menedzhmenta v sektore gosudarstvennykh uslug [Directions for improving financial management in the public services sector]. Bulletin REU them. G.V. Plekhanova, vol. 4(94), pp. 106-110.

8. Afanas'ev M.P., Krivogov I.V. (2007) Modernizatsiya gosudarstvennykh finansov [Modernization of public finance]. Moscow: State University - Higher School of Economics. (in Russian)

9. Kazakovtseva M.V. (2014) Otsenka effektivnosti finansovogo menedzhmenta v gosudarstvennom sektore [Assessment of the effectiveness of financial management in the public sector]. Models, systems, networks in economics, technology, nature and society, vol. 3(11), pp. 40-44.

10. Setting High Professional Standards for Public Services around the World. ACCA Report. Available at: http:// graduate.accaglobal.com/content/dam/acca/global/PDF-technical/public-sector/tech-tp-shps4.pdf (accessed 12 November 2019).

\section{СПЕЦИФИКА ФИНАНСОВОГО МЕНЕДЖМЕНТА В СФЕРЕ ГОСУДАРСТВЕННЫХ УСЛУГ}

Статья посвящена определению специфики и особенностей финансового менеджмента в сфере государственных услуг. Автором определена сущность финансового менеджмента и установлены основные отличия финансового менеджмента в сферах частных и государственных услуг. Проведен краткий анализ опыта ведущих стран мира в направлении развития финансового менеджмента в государственном секторе, среди которых такие страны, как Великобритания, Канада, Нидерланды, США. Установлены прочессы и процедуры, обеспечивающие результативность использования ресурсов финансового менеджмента в сфере государственных услуг. Особое внимание уделено автором вопросам совершенствования финансового менеджмента, руководства, управления эффективностью в организации данного сектора. В исследовании установлены основные проблемные аспекты развития системы финансового менеджмента и непосредственно управления его эффективности в государственном секторе в Украине, а также предложены пути преодоления ключевых недостатков.

Ключевые слова: финансовый менеджмент, государственный сектор, частный сектор, сфера государственных услуг, государственные услуги, инструменты финансового менеджмента, бюджет. 


\section{SPECIFICITY OF FINANCIAL MANAGEMENT IN THE PUBLIC SERVICES}

The article focuses on the specifics and features of financial management in public services. The author defines the essence of financial management, which should be understood as a system of management and control of financial aspects of the activity of a state body after achieving its goals, and establishes the main differences in financial management in the areas of private and public services, among which the differences in the following characteristics are identified: levels of application of financial management, objectives of financial management, objectives of financial management, risk management, the formation of financial resources. A brief analysis of the experience of the leading countries in the field of financial management development in the public sector, including countries such as the United Kingdom, Canada, the Netherlands, USA. The analysis identified that in a number of foreign countries, governments conduct internal assessments of the quality of financial management, which are then used in management practice. Most often, financial management quality assessment mechanisms are built into the executive power system and are elements of the monitoring and control system. Processes and procedures have been established to ensure the efficient use of financial management resources in public services. Particular attention is paid to the author's issues of improvement of financial management, leadership, performance management in the organization of this sector. These areas are considered a priority in many countries as governments seek to maintain financial sustainability in a volatile global economic environment. The study identifies the main problematic aspects of the development of the financial management system and the direct management of its efficiency in the public sector in Ukraine, as well as ways to overcome certain shortcomings, including the need to introduce information and analytical tools, improvement of information system of interaction on quality and control issues at all levels of management, optimization of indicators the efficiency of this system.

Key words: financial management, public sector, private sector, public services, public services, financial management tools, budget. 